\title{
Human papillomavirus-16 infection and p16 expression in oral squamous cell carcinoma
}

\author{
NORIHIKO TOKUZEN, KOH-ICHI NAKASHIRO, SHIN TOJO, \\ HIROYUKI GODA, NOBUYUKI KURIBAYASHI and DAISUKE UCHIDA
}

\begin{abstract}
Department of Oral and Maxillofacial Surgery, Ehime University Graduate School of Medicine, Toon, Ehime 791-0295, Japan
\end{abstract}

Received November 27, 2020; Accepted April 13, 2021

DOI: $10.3892 / \mathrm{ol} .2021 .12789$

\begin{abstract}
Human papillomavirus (HPV) is a possible carcinogenetic factor in oral squamous cell carcinoma (OSCC). Previous studies have reported the prevalence of HPV in patients with OSCC. However, the association between HPV and OSCC remains controversial. The present study aimed to clarify the association between HPV infection, p16 protein expression and the clinicopathological characteristics of OSCC. The expression level of HPV-16E6 mRNA and p16 protein, a known surrogate marker of HPV infection, was investigated in 100 OSCC cases using TaqMan reverse transcription-quantitative PCR and immunohistochemistry staining, respectively. HPV-16E6 mRNA expression level was only detected in one case (1\%), and positive expression of p16 was found in 10 cases (10\%), including an HPV-positive case. Subsequently, the association between p16 expression level and clinicopathological characteristic factors were analyzed; however, no significant association was found. These results suggested that HPV-16 infection was less likely to cause OSCC in Japan and p16 expression was not a suitable marker for HPV infection in OSCC.
\end{abstract}

\section{Introduction}

Oral squamous cell carcinoma (OSCC) is the most frequent type of head and neck squamous cell carcinoma (HNSCC), with $>500,000$ new cases annually worldwide (1). OSCC is more likely to invade local tissues and spread to the lymph nodes, and has a mortality rate of $\sim 50 \%$ within five years (2).

Correspondence to: Dr Koh-ichi Nakashiro, Department of Oral and Maxillofacial Surgery, Ehime University Graduate School of Medicine, 454 Shitsukawa, Toon, Ehime 791-0295, Japan

E-mail: nakako@m.ehime-u.ac.jp

Abbreviations: HPV, human papillomavirus; OSCC, oral squamous cell carcinoma

Key words: head and neck squamous cell carcinoma, human papillomavirus, infection, oral squamous cell carcinoma, p16
Despite the increasing knowledge into the etiology of OSCC and the advances in chemotherapy, radiation and surgery, there has been little improvement in the relative survival time in patients with OSCC in recent decades (2). Smoking and drinking are major risk factors for OSCC (3). In addition, infection with human papillomavirus (HPV) has been identified as another risk factor for developing carcinoma in the oral cavity (4).

HPV is a circular double-stranded DNA molecule, $\sim 8 \mathrm{~kb}$ and over 100 genotypes have been reported (5). The high-risk types, HPV-16 and 18 have been associated with $90 \%$ of uterine cervical cancers (6-8). The HPV genome is composed of early and late genes, which encode the early proteins, E1 to E7, and the late proteins L1 and L2. Among these genes, E6 and E7 have critical functions in malignant transformation of squamous cells (9). E6 binds to TP53 and inactivates its function by ubiquitin-dependent degradation (10). E7 manipulates and degrades the retinoblastoma tumor suppressor protein $(\mathrm{Rb})$, resulting in the activation of the transcription factor E2F, which enhances the expression of the cyclin-dependent kinase inhibitor 2A (CDKN2A; p16) (11). The expression of the p16 protein has been used as a surrogate marker for HPV infection in HNSCC (12).

The relevance of HPV infection in cervical cancer and HNSCC is well-known. Patients with HNSCC and are HPV-positive have an improved prognosis compared with those who are HPV-negative (13). According to a systematic review on HPV detection among 4,852 HNSCC cases worldwide, the overall prevalence rate of HPV was $34.5 \%$ (14). HPV-16 and 18 are the most common genotypes in HPV-positive OSCC, with a frequency rate of $32.4 \%(204 / 630)$ and $11.3 \%(71 / 630)$, respectively (15). Another systematic review on HPV infection, in patients with OSCC, reported that the prevalence rate of HPV was $55.5 \%(76 / 137)$ and the most common genotype was HPV-16 (16).

However, the association between HPV infection and OSCC remains unclear. For example, the prevalence of HPV in patients with OSCC varies in different regions worldwide $(17,18)$. In addition, a wide range of HPV prevalence was observed among patients from Japan (0-78\%) (19-23). The present study aimed to determine the prevalence of HPV and clarify the association between HPV-16 infection, p16 protein expression and clinicopathological characteristics of OSCC. 


\section{Materials and methods}

Patients and samples. Tissue samples were obtained from 100 patients with OSCC, including basaloid squamous cell carcinoma (BSCC), who underwent surgical resection at the Department of Oral and Maxillofacial Surgery at Ehime University Hospital (Ehime, Japan) between April 2004 and March 2013. Tumor staging was assessed according to the Union for International Cancer Control TNM Classification of Malignant Tumors 7th Edition and histological grading was performed according to the World Health Organization criteria for OSCC (24). The Institutional Review Board of Ehime University Hospital (Ehime, Japan) approved the present study.

Immunohistochemistry. Surgically resected OSCC specimens were fixed in $10 \%$ phosphate-buffered formalin for $24 \mathrm{~h}$ at room temperature and embedded in paraffin. A series of $4-\mu \mathrm{m}$ thick sections were prepared from each sample. Immunohistochemical (IHC) staining was performed using the avidin-biotin-peroxidase complex method. Briefly, the sections were deparaffinized and heated at $121^{\circ} \mathrm{C}$ in an autoclave for $20 \mathrm{~min}$ in $10 \mathrm{mM}$ citrate buffer ( $\mathrm{pH} \mathrm{6.0)}$ to regenerate epitopes. The sections were incubated with $0.3 \%$ hydrogen peroxide in distilled water for $5 \mathrm{~min}$ at room temperature to block endogenous peroxidase activity. The sections were then incubated overnight at $4^{\circ} \mathrm{C}$ with a specific mouse monoclonal antibody to anti-human p16 (cat. no. 550834; diluted 1:50; BD Pharmingen; BD Biosciences). After washing with TBS+Tween-20 (TBS-T; Sigma-Aldrich; Merck KGaA), the sections were overlaid with biotinylated anti-mouse antibody (Maravai LifeSciences) at room temperature for $60 \mathrm{~min}$, washed with TBS-T, then labeled with streptavidin-peroxidase complex (Maravai LifeSciences). The sections were subsequently counterstained with hematoxylin for $10 \mathrm{sec}$ at room temperature, dehydrated with a series of graded ethanols $(75,95,100$ and $100 \%)$ for $5 \mathrm{~min}$ each at room temperature, treated with xylene and enclosed in synthetic resin. IHC staining was observed at x40 and x100 magnifications under a light microscope (Nikon Corporation). Positive expression of p16 protein was determined as when $>70 \%$ of tumor cells showed strong and diffuse nuclear and cytoplasmic staining.

RNA extraction and RT-qPCR. Total RNA was extracted using ISOGEN (Nippon Gene) from lysing the tissues, after homogenization, with a TissueLyser (Qiagen), according to the manufacturer's protocol.

The presence of HPV-16E6 mRNA in the tissues was determined using RT-qPCR and the TaqMan ${ }^{\circledR}$ RNA-to- $\mathrm{C}_{\mathrm{T}}{ }^{\mathrm{TM}}$ 1-Step kit (Thermo Fisher Scientific, Inc.). PCR amplification was performed in a $10-\mu 1$ final reaction mixture containing $0.25 \mu \mathrm{l}$ TaqMan ${ }^{\circledR}$ RT Enzyme Mix (40X), $5 \mu$ l TaqMan ${ }^{\circledR}$ RT-PCR Mix (2X), $0.4 \mu 1$ each forward and reverse primers (10 $\mu \mathrm{M}$ each), $0.2 \mu 1$ TaqMan ${ }^{\circledR}$ probe $(10 \mu \mathrm{M})$ and $1 \mu$ l total RNA (100 ng/ $\mu \mathrm{l})$. The following thermocycling conditions were used: RT at $48^{\circ} \mathrm{C}$ for $15 \mathrm{~min}$, then initial denaturation at $95^{\circ} \mathrm{C}$ for $10 \mathrm{~min}$, followed by 40 cycles at $95^{\circ} \mathrm{C}$ for $15 \mathrm{~min}$ and $60^{\circ} \mathrm{C}$ for $1 \mathrm{~min}$. Oropharyngeal cancer tissues from biopsy materials obtained from patients with tonsil cancer treated in the Department of Oral and Maxillofacial Surgery at Ehime
University Hospital were used as the positive control. Written informed patient consent was obtained.

The expression of HPV-18E6 mRNA was detected using RT-qPCR and the SYBR ${ }^{\circledR}$ system. PCR amplification was performed in a $10-\mu 1$ final reaction mixture containing $5 \mu 1$ 2X One Step SYBR ${ }^{\circledR}$ RT-PCR Buffer 4, $0.4 \mu 1$ PrimeScript ${ }^{\circledR}$ One Step Enzyme Mix 2, $0.2 \mu 1$ ROX reference Dye II (50X), $2.6 \mu 1$ RNase-free distilled water (all from Takara Bio, Inc.), $0.4 \mu \mathrm{l}$ forward and reverse primers $(10 \mu \mathrm{M}$ each) and $1 \mu \mathrm{l}$ total RNA (100 ng/ $\mu \mathrm{l})$. The following thermocycling conditions were used: RT at $45^{\circ} \mathrm{C}$ for $5 \mathrm{~min}$ and $95^{\circ} \mathrm{C}$ for $10 \mathrm{sec}$, followed by 40 cycles at $95^{\circ} \mathrm{C}$ for $5 \mathrm{sec}$ and $55^{\circ} \mathrm{C}$ for $30 \mathrm{sec}$.

Amplification and detection were performed using the ViiA $^{\mathrm{TM}} 7$ real-time PCR system (Thermo Fisher Scientific, Inc.). Hydroxymethylbilane synthase (HMBS) was used as an internal control. To confirm the amplicon size, the PCR products were electrophoresed on 3\% agarose gels (Bio-Rad Laboratories), stained with ethidium bromide for $5 \mathrm{~min}$ at room temperature, and visualized under an ultraviolet transilluminator (FAS-III; Toyobo Life Science).

The following primers and TaqMan ${ }^{\circledR}$ probe were used: HPV-16E6 forward, 5'-GAATGTGTGTACAAGCAACAG-3', reverse, 5'-TGGATTCCCATCTCTATATACTATGCAT-3' and TaqMan ${ }^{\circledR}$ probe, 5'-CGACGTGAGGTATATGACTTT GCTTTTCGG-3' (25); HPV-18E6 forward, 5'-CAGAAACCG TTGAATCCAGCA-3' and reverse, 5'-TTTCTCTGCGTC GTTGGAGTC-3' (25) and HMBS forward, 5'-CATGCAGGC TACCATCCATGTC-3' and reverse, 5'-GTTACGAGCAGT GATGCCTACCAA-3'.

Genomic DNA extraction and exonuclease V-qPCR. Genomic DNA was extracted from formalin fixed paraffin embedded (FFPE) OSCC tissues using a GeneRead DNA FFPE kit (Qiagen $\mathrm{GmbH}$ ). Exonuclease V (ExoV; New England BioLabs, Inc.) digestion was performed, as previously described (26). For detecting HPV-16E6 DNA, qPCR amplification was conducted in a 10- $\mu$ l final reaction mixture containing $5 \mu 12 \mathrm{X}$ PowerTrack $^{\mathrm{TM}}$ SYBR $^{\mathrm{TM}}$ Green Master Mix (Thermo Fisher Scientific, Inc.), $0.5 \mu \mathrm{l}$ each forward and reverse primers $(8 \mu \mathrm{M}$ each), $3 \mu$ l nuclease-free distilled water and $1 \mu 1$ genomic DNA $(10 \mathrm{ng} / \mu \mathrm{l})$ with or without ExoV digestion. The following thermocycling conditions were used: Enzyme activation at $95^{\circ} \mathrm{C}$ for $2 \mathrm{~min}$, followed by 40 cycles at $95^{\circ} \mathrm{C}$ for $15 \mathrm{sec}$ and $60^{\circ} \mathrm{C}$ for $1 \mathrm{~min}$. Amplification and detection was performed using a ViiA ${ }^{\mathrm{TM}} 7$ real-time PCR system (Thermo Fisher Scientific, Inc.). Human ribosomal 18S DNA (rDNA) was used as an internal control. To confirm the amplicon size, the PCR products were electrophoresed and visualized using an Agilent 2100 Bioanalyzer with the DNA 1000 kit (Agilent Technologies). The following primers were used: HPV-16E6 forward, 5'-GAG AACTGCAATGTTTCAGGACC-3' and reverse, 5'-TGTATA GTTTGCAGCTCTGTGC-3'; rDNA forward, 5'-GCAATT CCCCATGAACG-3' and reverse, 5'-GGGACTTAATCAACG CAAGC-3' (26).

Statistical analysis. $\chi^{2}$ or Fisher's exact tests was used to determine significant differences between 2 groups. The Kaplan-Meier method was applied for survival analysis after follow-up for 36 months. Differences in patient survival were determined using the log-rank test. $\mathrm{P}<0.05$ was considered 

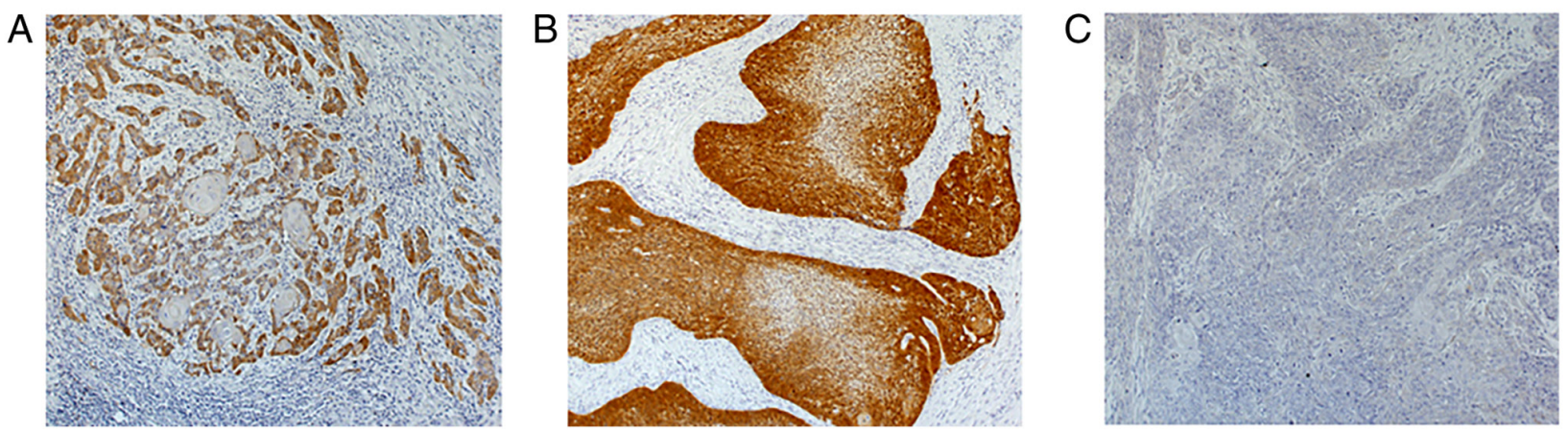

Figure 1. Immunohistochemical staining for p16 protein in oral squamous cell carcinoma tissues. (A) Positive expression in an HPV-16E6 mRNA negative case. (B) HPV-16E6 mRNA positive case showing strong and diffuse staining in the nucleus and cytoplasm of the tumor cells. (C) A representative image showing negative expression. Magnification, $\mathrm{x} 40$

to indicate a statistically significant difference. Statistical analyses were performed using GraphPad Prism software (v5.04; GraphPad Software, Inc.).

\section{Results}

Characteristics of the patients. The 100 OSCC cases included 54 men and 46 women, ranging in age from 39 to 93 years (median, 70.3 years). The primary tumor was located in the tongue $(n=36)$, mandibular gingiva $(n=31)$, maxillary gingiva $(n=13)$, floor of the mouth $(n=9)$, buccal mucosa $(n=9)$, or lower lip $(n=2)$. All the patients were histopathologically diagnosed with squamous cell carcinoma, including BSCC $(n=1)$.

Immunohistochemistry staining of pl6 protein. Positive expression of p16 protein was observed in 10 out of 100 OSCC cases (10\%). Most p16-positive cases showed strong and diffuse staining in the nucleus and the cytoplasm of the tumor cells (Fig. 1A and B). The association between p16 immunohistochemistry expression in the tumors from 100 patients with OSCC and their clinicopathological parameters was investigated; however, the differences were not significant (Table I). Furthermore, following the analysis between p16 expression and survival using the Kaplan-Meier method, no significant association between overall and disease-free survival times was found (Fig. S1).

Prevalence of HPV-16 in all patients with OSCC. To clarify HPV-16 infection, the expression level of HPV-16E6 mRNA in 100 OSCC cases was determined using RT-qPCR. HPV-16E6 mRNA expression was only detected in one case (1\%), which was also positive for 16 expression. PCR products of HPV-16E6 and HMBS were visualized using agarose gel electrophoresis (Fig. 2). HPV-18E6 mRNA expression was investigated in p16 positive OSCC tissues using RT-qPCR; however, it was not detected (data not shown). Furthermore, the possibility of persistent or silent infection with HPV-16 was investigated using genomic DNA derived from p16 positive OSCC cases using qPCR. HPV-16E6 DNA was detected in 3 out of 10 cases (Cases 1, 3 and 10; Fig. S2A). One of these cases expressed HPV-16E6 mRNA (Case 1), but the other cases did not (Case 3 and 10). Subsequently, genomic DNA was digested by ExoV, which preserved nicked and supercoiled DNAs but degraded linear DNAs, followed by qPCR for the detection of HPV-16E6 DNA. HPV-16E6 DNA was ExoV-resistant, suggesting that the circular episome was observed only in the HPV-16E6 DNA and mRNA positive case (Case 1; Fig. S2B). Since neither HPV-16E6 DNA nor RNA was detected in 7 of the 10 cases of p16 overexpression (Case 2, 4, 5, 6, 7, 8 and 9), the false-positive rate of HPV-16 infection was 70\%. Finally, only the HPV-16E6 DNA- and mRNA-positive case (Case 1) was histopathologically determined as BSCC, which is a rare variant of OSCC. The other cases (Case 3 and 10) were determined to be keratinized squamous cell carcinomas.

\section{Discussion}

HPV has been recognized as a possible pathogen of oral cancer (27-29). HPV has been associated with cancer of the uterus and cervix and was found in most cases (6-8). However, its role in oral carcinogenesis is still unknown (30-33). In oropharyngeal HNSCC, HPV-positive tumors may have different clinical and biological functions, with improved overall survival time and favorable prognosis (34). It has also been associated with therapeutic response in patients with HNSCC of the oropharynx (35). Another study showed that cases positive for HPV-16 had lower recurrence rates compared with that for their negative counterparts, indicating an association between HPV-16 infection and a good prognosis in OSCC (36). In contrast, HPV-16 infection reportedly enhanced the risk of distant metastasis and poor survival in patients with advanced OSCC (37). In the present study, the prevalence of HPV-16 in patients with OSCC was only $1 \%$. Therefore, the association between HPV infection and prognosis could not be evaluated.

Several techniques have been used to detect HPV. Examples include PCR, an HPV genotyping test, morphology, in situ hybridization and p16 immunohistochemistry. HPV detection methods, such as morphology, in situ hybridization and p16 immunohistochemistry lack sensitivity and specificity, as well as the ability to detect high-risk HPV types. Therefore, PCR was considered the most sensitive method $(38,39)$. The prevalence of HPV infection varied from $0 \%(19,40)$ to $100 \%(41)$, even in oral cavity cases. In the present study, p16 protein expression, which was used as a surrogate marker of HPV infection, was detected in $10 \%$ of cases, and the rate of HPV-16 infection with E6 expression was only $1 \%$ in 100 OSCC cases. The one case of HPV-16E6 mRNA positive expression also 
Table I. Association between p16 status and the characteristics of patients with oral squamous cell carcinoma.

\begin{tabular}{|c|c|c|c|}
\hline Characteristic & $\begin{array}{l}\text { p16-positive } \\
(\mathrm{n}=10)\end{array}$ & $\begin{array}{l}\text { p16-negative } \\
\quad(n=90)\end{array}$ & P-value \\
\hline Median age, years & 71 & 70 & 0.383 \\
\hline \multicolumn{4}{|l|}{ Sex } \\
\hline Male & 7 & 47 & 0.335 \\
\hline Female & 3 & 43 & \\
\hline Primary site & & & 0.185 \\
\hline Tongue & 1 & 35 & \\
\hline Maxillary gingiva & 2 & 11 & \\
\hline Mandibular gingiva & 3 & 28 & \\
\hline Floor of mouth & 2 & 7 & \\
\hline Buccal mucosa & 1 & 8 & \\
\hline Lip & 1 & 1 & \\
\hline Histological grading & & & 0.465 \\
\hline G1 & 7 & 56 & \\
\hline $\mathrm{G} 2$ & 3 & 22 & \\
\hline G3 & 0 & 12 & \\
\hline T-status & & & 0.077 \\
\hline $1 / 2$ & 4 & 63 & \\
\hline $3 / 4$ & 6 & 27 & \\
\hline N-status & & & 0.515 \\
\hline 0 & 5 & 55 & \\
\hline $1-3$ & 5 & 35 & \\
\hline Clinical stage & & & 0.504 \\
\hline $\mathrm{I} / \mathrm{II}$ & 3 & 42 & \\
\hline III/IV & 7 & 48 & \\
\hline Recurrence/metastasis & & & $>0.999$ \\
\hline No & 6 & 56 & \\
\hline Yes & 4 & 34 & \\
\hline
\end{tabular}

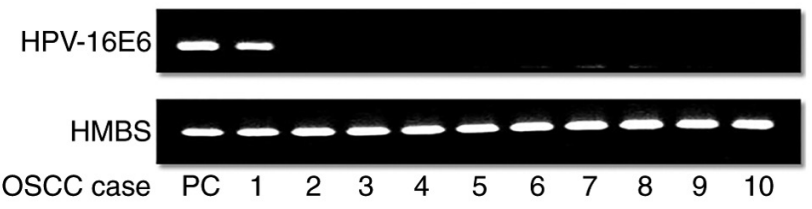

Figure 2. Expression of HPV-16E6 mRNA in p16 positive OSCC cases. The expression level of HPV-16E6 mRNA was analyzed using reverse transcriptionquantitative PCR. Only 1 case was found to be positive. HMBS was used as a loading control. PC, positive control; HMBS, hydroxymethylbilane synthase; OSCC, oral squamous cell carcinoma; HPV, human papillomavirus.

had expression of the p16 protein. To investigate the association between HPV-16 infection and p16 expression, the presence of HPV-16E6 DNA in genomic DNA samples, which were also p16 positive was determined and HPV-16E6 DNA was found not only in the E6 mRNA positive case, but also in additional 2 cases without E6 expression. The expression of p16 was also $70 \%$ HPV-16 false-positive, indicating the low reliability of the surrogate marker of HPV infection in OSCC. A previous study showed $100 \%$ HPV false-positive results in mobile tongue cancer (19). It suggested that although p16 protein expression was a biomarker for cervical or tonsillar cancer arising from carcinogenic HPV infection, it was not applicable for tongue cancer (19). Furthermore, another study indicated that p16 expression was not a suitable surrogate marker of HPV infection in oral lesions and HPV-16 infection was associated with BSCC (42). In fact, only one HPV-16E6 mRNA-positive case was histopathologically determined to be BSCC in the present study. However, both HPV-16E6 DNA positive cases, without E6 expression, were keratinized squamous cell carcinomas.

Most cervical and oropharyngeal cancers show high expression of E6 and E7; however, OSCC has a lower positive rate of E6 and E7 mRNA expression compared with that for HPV DNA positive rate (43). We have hypothesized that there are two types of HPV DNA positive OSCCs. One is HPV-related OSCC, which is a silent infection with no expression of E6 and E7, but is caused by the integration of HPV DNA into the genome. The other is non-keratinized OSCC with E6 and E7 expression, in which HPV DNA is actively infected as a nuclear episome and/or genome integration.

In summary, the results from the present study indicated that there were few OSCC cases due to HPV-16 infection. The expression of p16 protein was not an appropriate surrogate marker for HPV-16 infection in OSCC. In addition, HPV-16 DNA may also be detected in p16 negative OSCC cases. As the number of HPV-16 DNA positive cases was extremely low in the present study, further investigation is required to examine the presence of episomal and integrated HPV DNA and the expression of E6 and E7 mRNA, regardless of p16 expression, using the large number of fresh frozen OSCC tissues.

\section{Acknowledgements}

The authors would like to thank Ms Yumiko Fukuda (Department of Oral and Maxillofacial Surgery, Ehime University Graduate School of Medicine, Ehime, Japan) for providing technical assistance.

\section{Funding}

This study was supported by a Grant-in-Aid for Scientific Research (B) from the Japan Society for the Promotion of Science (grant no. 16H05543).

\section{Availability of data and materials}

The datasets used and/or analyzed during the current study are available from the corresponding author on reasonable request.

\section{Authors' contributions}

NT and KN confirm the authenticity of all the raw data. KN, NK and DU advised and supervised the study. KN designed the experiments. NT and ST performed the experiments. NT, $\mathrm{HG}, \mathrm{NK}$ and DU analyzed the data. NT and KN wrote the manuscript. All authors read and approved the final version of manuscript.

\section{Ethics approval and consent to participate}

The present study was approved by the Institute Research Ethics Committee of the Ehime University Hospital (approval 
number, 1607005) and written informed consent was provided by all the patients.

\section{Patient consent for publication}

Not applicable.

\section{Competing interests}

The authors declare that they have no competing interests.

\section{References}

1. Ferlay J, Shin HR, Bray F, Forman D, Mathers C and Parkin DM Estimates of worldwide burden of cancer in 2008: GLOBOCAN 2008. Int J Cancer 127: 2893-2917, 2010.

2. Gupta S, Kong W, Peng Y, Miao Q and Mackillop WJ: Temporal trends in the incidence and survival of cancers of the upper aerodigestive tract in Ontario and the United States. Int J Cancer 125: 2159-2165, 2009.

3. Blot WJ, McLaughlin JK, Winn DM, Austin DF, Greenberg RS, Preston-Martin S, Bernstein L, Schoenberg JB, Stemhagen A and Fraumeni JF Jr: Smoking and drinking in relation to oral and pharyngeal cancer. Cancer Res 48: 3282-3287, 1988.

4. Leemans CR, Braakhuis BJ and Brakenhoff RH: The molecular biology of head and neck cancer. Nat Rev Cancer 11: 9-22, 2011.

5. Dell G and Gaston K: Human papillomaviruses and their role in cervical cancer. Cell Mol Life Sci 58: 1923-1942, 2001.

6. zur Hausen H: Papillomaviruses and cancer: From basic studies to clinical application. Nat Rev Cancer 2: 342-350, 2002.

7. Clifford GM, Smith JS, Plummer M, Muñoz N and Franceschi S Human papillomavirus types in invasive cervical cancer worldwide: A meta-analysis. Br J Cancer 88: 63-73, 2003.

8. Bosch FX and de Sanjosé S: The epidemiology of human papillomavirus infection and cervical cancer. Dis Markers 23: 213-227, 2007.

9. Münger K, Baldwin A, Edwards KM, Hayakawa H, Nguyen CL, Owens M, Grace M and Huh K: Mechanisms of human papillomavirus-induced oncogenesis. J Virol 78: 11451-11460, 2004.

10. Narisawa-Saito $M$ and Kiyono T: Basic mechanisms of high-risk human papillomavirus-induced carcinogenesis: Roles of E6 and E7 proteins. Cancer Sci 98: 1505-1511, 2007.

11. McLaughlin-Drubin ME and Münger K: The human papillomavirus E7 oncoprotein. Virology 384: 335-344, 2009.

12. El-Naggar Ak and Westra WH: p16 expression as a surrogate marker for HPV-related oropharyngeal carcinoma: A guide for interpretative relevance and consistency. Head Neck 34: 459-461, 2012.

13. Deng Z, Hasegawa M, Yamashita Y, Matayoshi S, Kiyuna A, Agena S, Uehara T, Maeda $\mathrm{H}$ and Suzuki M: Prognostic value of human papillomavirus and squamous cell carcinoma antigen in head and neck squamous cell carcinoma. Cancer Sci 103: 2127-2134, 2012

14. Termine N, Panzarella V, Falaschini S, Russo A, Matranga D, Lo Muzio L and Campisi G: HPV in oral squamous cell carcinoma vs. head and neck squamous cell carcinoma biopsies: A meta-analysis (1988-2007). Ann Oncol 19: 1681-1690, 2008.

15. Sritippho T, Chotjumlong $P$ and Iamaroon A: Roles of Human Papillomaviruses and p16 in Oral Cancer. Asian Pac J Cancer Prev 16: 6193-6200, 2015

16. Hobbs CG, Sterne JA, Bailey M, Heyderman RS, Birchall MA and Thomas SJ: Human papillomavirus and head and neck cancer: A systematic review and meta-analysis. Clin Otolaryngol 31: 259-266, 2006

17. Castillo A, Koriyama C, Higashi M, Anwar M, Bukhari MH, Carrascal E, Mancilla L, Okumura H, Matsumoto M, Sugihara K, et al: Human papillomavirus in upper digestive tract tumors from three countries. World J Gastroenterol 17 : 5295-5304, 2011.

18. Krüger M, Pabst AM, Walter C, Sagheb K, Günther C, Blatt S, Weise K, Al-Nawas B and Ziebart T: The prevalence of human papilloma virus (HPV) infections in oral squamous cell carcinomas: A retrospective analysis of 88 patients and literature overview. J Craniomaxillofac Surg 42: 1506-1514, 2014

19. Kabeya M, Furuta R, Kawabata K, Takahashi S and Ishikawa Y: Prevalence of human papillomavirus in mobile tongue cancer with particular reference to young patients. Cancer Sci 103 : 161-168, 2012.
20. Shima K, Kobayashi I, Saito I, Kiyoshima T, Matsuo K, Ozeki S, Ohishi M and Sakai H: Incidence of human papillomavirus 16 and 18 infection and p53 mutation in patients with oral squamous cell carcinoma in Japan. Br J Oral Maxillofac Surg 38: 445-450, 2000.

21. Sugiyama M, Bhawal UK, Kawamura M, Ishioka Y, Shigeishi H, Higashikawa K and Kamata N: Human papillomavirus-16 in oral squamous cell carcinoma: Clinical correlates and 5-year survival. Br J Oral Maxillofac Surg 45: 116-122, 2007.

22. Rushatamukayanunt P, Morita K, Matsukawa S, Harada H, Shimamoto H, Tomioka H and Omura K: Lack of association between high-risk human papillomaviruses and oral squamous cell carcinoma in young japanese patients. Asian Pac J Cancer Prev 15: 4135-4141, 2014

23. Ono K, Sugahara K, Nomura T, Takano N, Shibahara T and Katakura A: Multiple HPV subtypes infection in Japanese oral Squamous cell carcinoma. J Oral Maxillofac Surg Med Pathol 26: 128-132, 2014.

24. International Union Against Cancer (UICC): TNM classification of malignant tumours. 7th edition. Sobin LH, Gospodarowicz MK and Wittekind C (eds). Willey-Blackwell, Hoboken, pp25-29, 2009.

25. Yamakawa-Kakuta Y, Kawanata H, Doi Y, Fujimori T and Imai Y: Does the expression of HPV16/18 E6/E7 in head and neck squamous cell carcinomas relate to their clinicopathological characteristics? Int J Oncol 35: 983-988, 2009.

26. Myers JE, Guidry JT, Scott ML, Zwolinska K, Raikhy G, Prasai K, Bienkowska-Haba M, Bodily JM, Sapp MJ and Scott RS: Detecting episomal or integrated human papillomavirus 16 DNA using an exonuclease V-qPCR-based assay. Virology 537: 149-156, 2019.

27. Anaya-Saavedra G, Ramírez-Amador V, Irigoyen-Camacho ME, García-Cuellar CM, Guido-Jiménez M, Méndez-Martínez R and García-Carrancá A: High association of human papillomavirus infection with oral cancer: A case-control study. Arch Med Res 39: 189-197, 2008

28. Iamaroon A, Pattanaporn K, Pongsiriwet S, Wanachantararak S, Prapayasatok S, Jittidecharaks S, Chitapanarux I and Lorvidhaya V: Analysis of 587 cases of oral squamous cell carcinoma in northern Thailand with a focus on young people. Int J Oral Maxillofac Surg 33: 84-88, 2004.

29. Lee SY, Cho NH, Choi EC, Baek SJ, Kim WS, Shin DH and Kim SH: Relevance of human papilloma virus (HPV) infection to carcinogenesis of oral tongue cancer. Int J Oral Maxillofac Surg 39: 678-683, 2010.

30. Doorbar J: The papillomavirus life cycle. J Clin Virol 32 Suppl 1: S7-S15, 2005

31. Ibieta BR, Lizano M, Fras-Mendivil M, Barrera JL, Carrillo A, Ma Ruz-Godoy L and Mohar A: Human papilloma virus in oral squamous cell carcinoma in a Mexican population. Oral Surg Oral Med Oral Pathol Oral Radiol Endod 99: 311-315, 2005.

32. Llamas-Martínez S, Esparza-Gómez G, Campo-Trapero J, Cancela-Rodríguez P, Bascones-Martínez A, Moreno-López LA, García-Núñez JA and Cerero-Lapiedra R: Genotypic determination by PCR-RFLP of human papillomavirus in normal oral mucosa, oral leukoplakia and oral squamous cell carcinoma samples in Madrid (Spain). Anticancer Res 28 (6A): 3733-3741, 2008.

33. Uobe K, Masuno K, Fang YR, Li LJ, Wen YM, Ueda Y and Tanaka A: Detection of HPV in Japanese and Chinese oral carcinomas by in situ PCR. Oral Oncol 37: 146-152, 2001.

34. Marur S, D'Souza G, Westra WH and Forastiere AA: HPV-associated head and neck cancer: A virus-related cancer epidemic. Lancet Oncol 11: 781-789, 2010.

35. Fakhry C, Westra WH, Li S, Cmelak A, Ridge JA, Pinto H, Forastiere A and Gillison ML: Improved survival of patients with human papillomavirus-positive head and neck squamous cell carcinoma in a prospective clinical trial. J Natl Cancer Inst 100: 261-269, 2008.

36. Elango KJ, Suresh A, Erode EM, Subhadradevi L, Ravindran HK, Iyer SK, Iyer SK and Kuriakose MA: Role of human papilloma virus in oral tongue squamous cell carcinoma. Asian Pac J Cancer Prev 12: 889-896, 2011.

37. Lee LA, Huang CG, Liao CT, Lee LY, Hsueh C, Chen TC, Lin CY, Fan KH, Wang HM, Huang SF, et al: Human papillomavirus-16 infection in advanced oral cavity cancer patients is related to an increased risk of distant metastases and poor survival. PLoS One 7: e40767, 2012

38. Schlecht NF, Brandwein-Gensler M, Nuovo GJ, Li M, Dunne A, Kawachi N, Smith RV, Burk RD and Prystowsky MB: A comparison of clinically utilized human papillomavirus detection methods in head and neck cancer. Mod Pathol 24: 1295-1305, 2011. 
39. Pannone G, Rodolico V, Santoro A, Lo Muzio L, Franco R, Botti G, Aquino G, Pedicillo MC, Cagiano S, Campisi G, et al: Evaluation of a combined triple method to detect causative HPV in oral and oropharyngeal squamous cell carcinomas: p16 immunohistochemistry, consensus PCR HPV-DNA, and in situ hybridization. Infect Agent Cancer 7: 4, 2012.

40. de Spíndula-Filho JV, da Cruz AD, Oton-Leite AF, Batista AC, Leles CR, de Cássia Gonçalves Alencar R, Saddi VA and Mendonça EF: Oral squamous cell carcinoma versus oral verrucous carcinoma: An approach to cellular proliferation and negative relation to human papillomavirus (HPV). Tumor Biol 32: 409-416, 2011.

41. Koyama K, Uobe K and Tanaka A: Highly sensitivity detection of HPV-DNA in paraffin sections of human oral carcinomas. J Oral Pathol Med 36: 18-24, 2007.
42. Friedrich RE, Sperber C, Jäkel T, Röser K and Löning T: Basaloid lesions of oral squamous epithelial cells and their association with HPV infection and P16 expression. Anticancer Res 30: 1605-1612, 2010.

43. Ndiaye C, Mena M, Alemany L, Arbyn M, Castellsagué X, Laporte L, Bosch FX, de Sanjose S and Trottier H: HPV DNA, E6/E7 mRNA, and p16INK4a detection in head and neck cancers: A systematic review and meta-analysis. Lancet Oncol 15: 1319-1331, 2014.

This work is licensed under a Creative Commons Attribution-NonCommercial-NoDerivatives 4.0 International (CC BY-NC-ND 4.0) License. 